\title{
X-RAY CRANIOMETRIC AND X-RAY CEPHALOMETRIC DETERMINATION OF ANGULAR PARAMETERS IN GERMAN SHEPHERD DOGS
}

\author{
KRSTIĆ N*, PEŠUT OLIVERA*, MARKOVIĆ D**, TEPAVČEVIĆ ZVEZDANA**, HADŽI MILIĆ M* \\ and MILOSAVLJEVIĆ Ž゙** \\ *University of Belgrade, Faculty of Veterinary Medicine, Belgrade, Serbia; \\ **University of Belgrade, Faculty of Dental Medicine, Belgrade, Serbia
}

(Received 13. December 2008)

Analyses of the viscerocranial parameters in dogs has been avoided due to inconsistencies in defining the reference points for linear and angular measurements. In our study we classified the elements which refer to the balance of skeletal structures and teeth in relation to other osseous elements. By X-ray-photoimaging spatial relations within the osseous system of the head of German Shepherd dogs angular parameters (gonial angle Go, the angles IV, SNA, SNB, $A N B$ and NSBa) were constructed. Sagittal positions or inclinations of the upper and lower incisors were determined by angles $C$ and $D$ and their relationship was determined by the interincisal angle $E$. The position of the upper and lower eyeteeth in relation to the basic plane of the maxilla and mandible was determined by the numerical values of angles $F$ and $G$. The opportunity to define the type of growth, and the changes between the face and the skull base, was provided by constructing the following angles of the polygon, as well as by the exact determination of their individual and total values: <SarGo, <NSAr, $<$ ArGolv, <GolvMe.

Key words: dog, radiocephalometry, radiocraniometry, radiology, teleroentgen

\section{INTRODUCTION}

There is few data on tele-X-ray analysis of the viscerocranium anatomy and development in animals because of the technical difficulties encountered and because of numerous disagreements in defining the reference points for linear and angular measurements amply described in the work of Scott $(1964,1967)$.

In our study we performed X-ray photographing on anesthetized dogs placed in the costo-abdominal position with the central X-ray directed immediately behind the orbit. The position of the head was checked with a horizontal line on the $\mathrm{x}$-ray table and with an illuminating marker fixed to the X-ray apparatus. This simple procedure of obtaining isometric radiograms makes possible the application of this method in clinical practice. 
Although X-ray craniometry and X-ray cephalometry have been used in human medicine for over 60 years (Hofrath, 1931; Broadbent, 1931) there is still not a unique method for selecting and positioning the points, planes and angles as there are different parameters defined by different authors (Korkhaus, 1936; Downs, 1948; Steiner, 1953).

To make an analogy between literature data, which refer to parameters used in cephalometry and craniometry in human medicine (Whyllie, 1947; Hoffer, 1954; Sassouni, 1955; Bimmler, 1967; Goldstein, 1988; Gans and Sarnat, 1989) and the equivalent anatomical entities in dogs is possible only to a certain extent. Peculiarities of shape and size of the features of a dog's head require a special selection of points, planes and angles relevant for making evaluations of morphological characteristics and adjustments between certain anatomical regions (Mc Keonin, 1975; Kavanagh, 1988; Kraut, 1990).

By means of X-ray-craniometric and X-ray-cephalometric analyses of the relevant reference points in German Shepherd dogs, linear parameters were determined which could be used for the classification of the neuroviscerocranium of these animals (Krstic et al., 2002).

Regular proportions of certain facial and head regions were exactly determined by defining and numerically expressing the following lines: line $N$ (Nasion)-S (Sella), bi-spinal or palatine plane alpha (SnA-SnP), occlusive planebeta, plane gamma (Go-Me) and the line N-A. The line N-lv was the average height of the face, typical for the mezocephalic dog head type. Lines Co (Condylion)-Go (Gonion), Go (Gonion) -Me (Menton) and the line S (Sella)-Go (Gonion) were defined, as well. A full insight in the aesthetic arrangement and anatomic balance of the proportions was obtained by determining the following linear parameters on the frontal photograph: the line Zy-Zy (Zygion), Eu-Eu (between the points Eurion), line Em-Em, ecm-ecm, Eim-Eim, Go-Go, En-En, Ein-Ein, Ecm-Ecm, EcpEcp and Ecl-Ecl. These parameters were defined for the osseous elements and for the soft tissues of the viscero- and neurocranium.

\section{MATERIAL AND METHODS}

Clinical experience indicated that malocclusions are frequently found in highly selected dog breeds. As an experimental model we used 15 dogs of the German Shepherd breed. They belonged to a homogenous group from two litters, 12 months old, male, with body mass of 25 to 30 kilograms. All recordings were made on animals under general anesthesia. Teleradiography was used to obtain isometric radiographs. This procedure can provide reliable particulars of the actual size of bone structures of the head and jaws. During preliminary testing, the most suitable $x$-rays were determined to be $65 \mathrm{kV}$ and $24 \mathrm{~mA}$. Exposure time amounted to 0.03 seconds and the film focus distance was $1.5 \mathrm{~m}$.

In order to prevent lateral head inclination, the animals were placed in the costoabdominal position and only the position of the central $\mathrm{X}$ ray was changed depending whether profile of frontal photographs were required. Care was taken that the median of the dog's body always coincided with the white mid-line on the photographic table. After film processing, bone and skin contours that were 
Acta Veterinaria (Beograd), Vol. 59. No. 2-3, 255-265, 2009.

Krstić $\mathrm{N}$ et al.: X-ray craniometric and X-ray cephalometric

necessary for correct and valid measurements were drawn on acetate paper, which has been previously fixed to the photograph.

Statistical analysis was performed after calculating the mean values (M), standard deviations (SD), standard error (SE) and coefficient of variation (CV\%).

\section{RESULTS}

To determine the spatial relations of the osseous system of the head in the German Shepherd breed, in the profile (LL) projection, the following angles were measured:

Angle Go - is the gonial angle and is formed at the intersection of the line drawn from points Ar-Go and the line gamma which describes the mandible plane (101.0 \pm 7.2) (Figure 1 and Table 1).

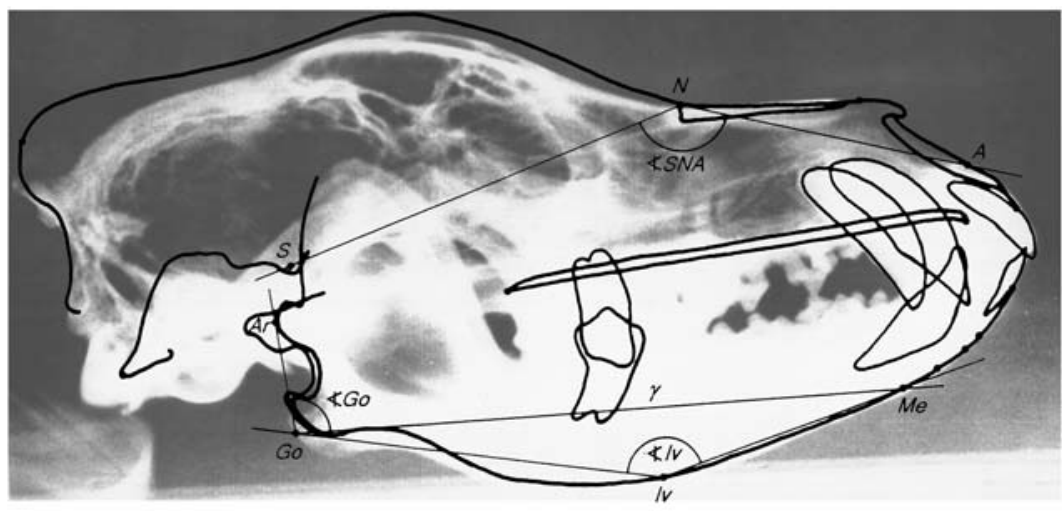

Figure 1. Profile radiocraniometric Go, Iv and SNA angles

Table 1. Descriptive statistical parameters of the angular craniometric measurements

\begin{tabular}{|l|c|c|c|c|c|c|}
\hline \multicolumn{1}{|c|}{ Angle } & $\mathrm{M}$ & $\mathrm{SD}$ & $\mathrm{SE}$ & $\mathrm{CV}(\%)$ & Min-Max & Med \\
\hline \hline$<\mathrm{B}$ & 14.9 & 2.2 & 0.5 & 14.8 & $10-19$ & 15.0 \\
\hline$<\mathrm{IV}$ & 153.2 & 3.5 & 0.9 & 2.3 & $148-160$ & 153.0 \\
\hline$<$ Go & 101.0 & 7.2 & 1.8 & 7.1 & $83-110$ & 102.0 \\
\hline$<\mathrm{SNA}$ & 143.8 & 3.5 & 0.9 & 2.4 & $136-149$ & 145.0 \\
\hline$<\mathrm{SNB}$ & 122.1 & 4.9 & 1.2 & 4.0 & $112-129$ & 123.0 \\
\hline$<\mathrm{ANB}$ & 22.1 & 4.0 & 1.0 & 18.1 & $14-27$ & 24.0 \\
\hline$<\mathrm{NSBa}$ & 160.0 & 5.9 & 1.5 & 3.7 & $149-169$ & 163.0 \\
\hline
\end{tabular}


Angle $B$ - denotes the angle of the body of the mandible, constructed at the intersection of the lines where one of them was a tangent of the outer osseous shadow of the mandible in the point I, and the other one was the plane SnA-SnB (basic plane of the maxilla). Value of this angle was $14.9 \pm 2.2$ (Figure 2 and Table 1).

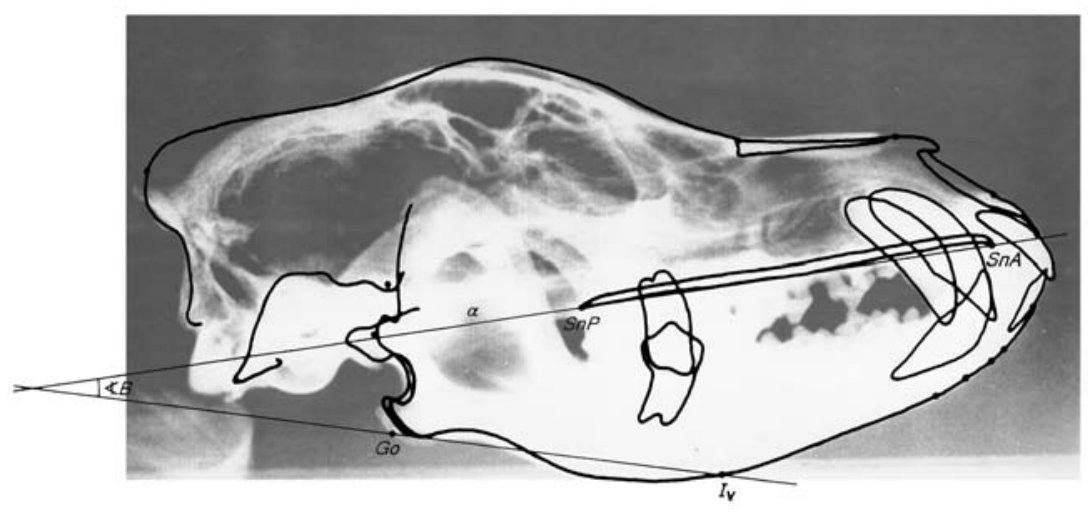

Figure 2. Radiocraniometric angle B in the profile projection

Angle IV - denotes the angle of the mandible body, constructed at the intersection of the lines which touched the outer osseous shadow of the mandible, starting from the point Menton at the rostral side of the mandible and the point Gonion. Values of this angle ranged from 148 to 160 degrees having the average value of $153.2 \pm 3.5$ degrees.

Angle SNA - by means of this angle the position of the maxilla in relation to the neurocranium was defined. Thus, we defined the rostrocaudal position of point $A$ in relation to the skull base. Angle SNA $(143.8 \pm 3.5)$ was defined at the intersection of the lines SN and NA (Figure 1 and Table 1).

Angle SNB - constructed at the intersection of lines SN and NB $(122.1 \pm$ 4.9), defines the position of the mandible in relation to the neurocranium (Figure 3 and Table 1).

Angle ANB - is the difference between angles SNA and SNB, and it denotes a sagittal relation between the bodies of the maxilla and mandible $(22.1 \pm 4.0)$ (Figure 3 and Table 1).

Angle NSBa - was obtained at the intersection of lines NS and BaS (160.0 \pm 5.9 ), it defines the angle of the skull base (Figure 3 and Table 1).

Angle $C$ - by this angle we determined the sagittal position or incline of the upper central incisors in relation to the maxilla. The angle $C$ was structurally obtained at the intersection of the line which passed through the central axis of the upper incisors and the line alpha, i.e. the basic plane of the maxilla (Figure 4 and Table 2). 
Acta Veterinaria (Beograd), Vol. 59. No. 2-3, 255-265, 2009.

Krstić $\mathrm{N}$ et al.: X-ray craniometric and X-ray cephalometric

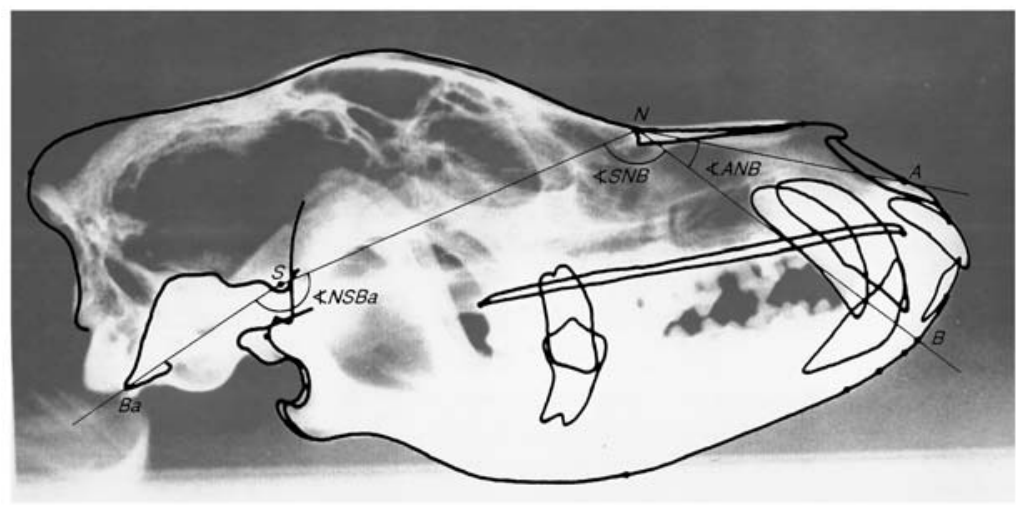

Figure 3. Radiocraniometric angles SNB, ANB and NSBa in the profile projection

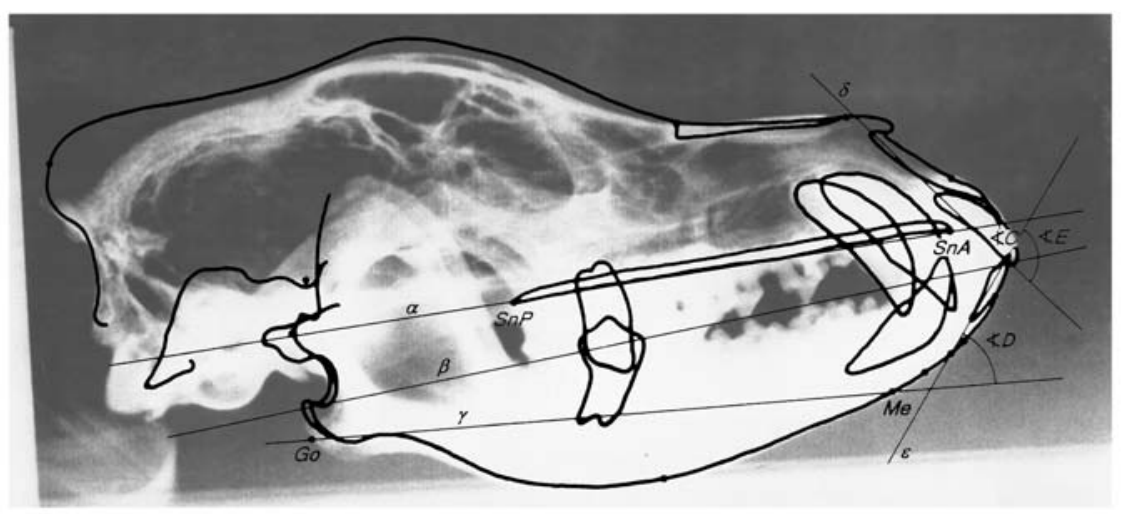

Figure 4. Radiocraniometric angles C, D and E in the profile projection

Table 2. Descriptive statistical parameters of the incisors and eyeteeth inclines of the maxilla and mandible

\begin{tabular}{|c|c|c|c|c|c|c|}
\hline Angle & $\mathrm{M}$ & $\mathrm{SD}$ & $\mathrm{SE}$ & $\mathrm{CV}(\%)$ & Min-Max & Med \\
\hline \hline$<\mathrm{C}$ & 61.3 & 6.4 & 1.6 & 10.4 & $50-74$ & 60.0 \\
\hline$<\mathrm{D}$ & 52.3 & 5.9 & 1.5 & 11.3 & $37-60$ & 52.0 \\
\hline$<\mathrm{E}$ & 110.3 & 11.5 & 2.9 & 10.4 & $83-127$ & 111.0 \\
\hline$<\mathrm{F}$ & 66.5 & 3.5 & 0.9 & 5.3 & $62-75$ & 66.0 \\
\hline$<\mathrm{G}$ & 46.1 & 5.7 & 1.4 & 12.4 & $39-60$ & 45.0 \\
\hline
\end{tabular}


Angle $D$ - determines the inclination of the lower central incisors in relation to the mandible. As a base for its determination the line gamma or the basic plane of mandible and the axis of the lower incisors were applied (Figure 4 and Table 2).

Angle $E$ - by this angle we found out the interincisal angle (110.3 \pm 10.5$)$, or the relation between positions of upper and lower incisives (Figure 4 and Table 2).

Angles $F$ and $G$ - by means of these angles we set the position of the upper and lower canine teeth in relation to the basic plane of the maxilla and mandible. The values of the angle $F$ were from 62 to 75 degrees $(66.5 \pm 3.5)$, and the values of the angle $\mathrm{G}$ were from 39 to 60 degrees (46.1 \pm 5.7$)$ (Figure 5 and Table 2).

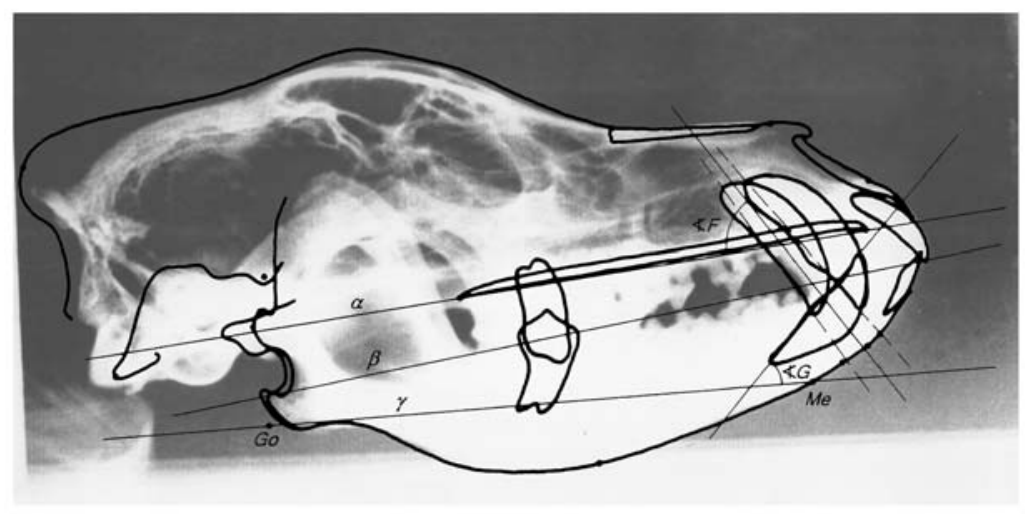

Figure 5. Radiocraniometric angles $F$ and $G$ in the profile projection

In our study we analysed the following four angles which form a polygon in human X-ray-craniometry. These were the angles SArGo and NSAr, ArGolv and GolvMe. The angles SArGo and NSAr were formed by lines which were not in the same plane (Figure 6 and Table 3).

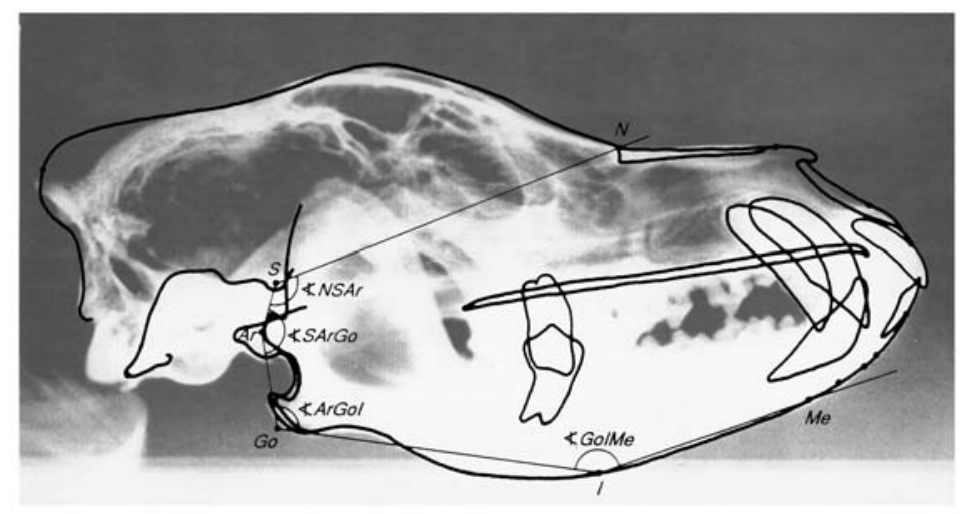

Figure 6. Polygon in the profile projection 
Acta Veterinaria (Beograd), Vol. 59. No. 2-3, 255-265, 2009.

Krstić $\mathrm{N}$ et al.: X-ray craniometric and X-ray cephalometric

determination of angular parameters in German Shepherd dogs

Table 3. Descriptive statistical parameters of the examined measurements of the head polygon

\begin{tabular}{|l|c|c|c|c|c|c|}
\hline \multicolumn{1}{|c|}{ Angle } & M & SD & SE & CV (\%) & Min-Max & Med \\
\hline \hline <NSAr & 120.5 & 4.5 & 1.1 & 3.7 & $113-127$ & 120.0 \\
\hline$<$ SarGo & 150.4 & 9.9 & 2.5 & 6.3 & $134-175$ & 150.0 \\
\hline$<$ ArGolv & 103.6 & 4.2 & 1.1 & 4.0 & $97-110$ & 103.0 \\
\hline$<$ GolvMe & 152.7 & 3.5 & 0.9 & 2.3 & $148-160$ & 152.0 \\
\hline$\Sigma$ (sum) & 526.9 & 13.8 & 3.5 & 2.6 & $507-548$ & 527.0 \\
\hline
\end{tabular}

\section{DISCUSSION}

According to Steiner (1953) the basic plane of the frontal part of the human skull base is bordered with points $\mathrm{N}$ and $\mathrm{S}$ which coincide with the properties of the dog head. To determine the skeletal relationships of the viscerocranium in men, angles SNA and SNB were constructed and measured. Each of the angles individually shows the relation of the jaws to the skull base, while the difference presented by the angle ANB shows the type of sagittal relationship between the maxilla and mandible.

The first angle in our diagrams was marked as SNA and its mean value in normal occlusion is 143.8 degrees. If the maxilla is inclined forward anteinclination, it increases, and if the maxilla is inclined backward retroinclination, it decreases. With the maxilla inclining, point $(A)$ moves forward in the case of anteinclination, or backward in the case of retroinclination. This explains why with each inclination change of the maxilla the position of the face also changes.

The position of the mandible in relation to the frontal part of the cranium base (NS line) is shown by angle SNB (mean value in normo-occlusion is 122.1 degrees). Changes in the measured values in the sense of its increasing speak for the progeny of the mandible, and if decreasing, for a distal bite. However, if both angles are increasing simultaneously, then the jaws are developing forward, and if the angles are decreasing simultaneously, then a skeletal disorder in a form of jaw shortening is occurring. The knowledge and determination of these parameters can directly influence the selection of the method for oral surgery (Liu et al., 1998; Hollier et al., 2000; Nadjmi et al., 2003; Wang et al., 2006).

Angle ANB is given by the difference between angles SNA and SNB, deviations from the average value of this angle make it possible to determine the required corrections.

The angle made by the basic planes of the maxilla and mandible (B) represents their vertical correlation, and its value ranges from 10 to 19 degrees. If the correlation between the jaws is neutral, and angle $(B)$ is larger than the maximum one (19 degrees), the area of the chin will move backward and downward and thus the points $(\mathrm{B})$ and $(\mathrm{Pg})$ will move backward and vice versa. 
The most ventral internal angle of the dog head (IV), which is formed by the lines Melv and Golv, does not have its equivalent model in human X-raycraniometry. Due to the difference in morphology of the lower edge of the mandible, which has an impression in point (Iv) in dogs, this angle is relevant as a parameter for the inclination of the mandible body - the line Golv. The points which are in the rostral section of the mandible (Id, Pg, B, Sm, Gn, Me), influence the size of the angle (Iv). Its reduction results in the mandible extending forward and upward and its increase will lead to the mandible extending backward and downward.

The angles which define a normal teeth occlusion in a dog of the German Shepherd breed, refer to the position of the incisors and canines in relation to the basic plane of the maxilla and mandible.

Studies, related to the estimation of normal occlusion, in human medicine (Angle, 1913; Lundstrom, 1948) did not take into account the function of dentition. In veterinary medicine teeth function is of importance since it affects their morphology and position (Ross, 1986; Kyle, 1988).

If we look at the inclination of the upper incisors in relation to the basic plane of the maxilla (alpha) we can see that the values of angle $C$ range from 50 to 74 degrees. Angle D, which represents the inclination of the lower incisors towards the basic plane of the mandible, ranges from 37 to 60 degrees. It can be concluded that the inclinations of the incisors of the maxilla and mandible have the same variation range. However, the variation range of angle $F$, which represents the inclination of eyeteeth of the maxilla, is less than 21 degrees. These differences do not indicate an occlusion disorder because as the teeth are placed in an arc-shaped position they are in harmony with neighboring teeth within the same and the opposite arcs. The established ranges of angle values are within the permitted individual variations and they represent common general features, as well as individual characteristics of each animal. Therefore, it is of greater importance to take individual values than to take the standard mean values. All these results are valid only for the examined age period of the animals as they significantly change with growth.

Individual differences in appearance, as well as the position and inclinations of teeth in the maxilla in relation to the mandible depend primarily on hereditary factors (Bodmer and Cavalli Sforza, 1976; Dixon and Stewart, 1976), but also on nutrition, health status, etc. Sometimes an almost ideal morphological occlusion can be accompanied with serious functional disturbances due to a disorder in the temporomandibular joint thouroughly described by Goodman and Gorlin (1977).

During head growth, the relationship between the face and the base of the cranium changes. According to these changes, three basic types of growth can be classified (Clutton-Brock et al., 1976):

1. vertical (brachycephalous - Bulldog, Boxer),

2. horizontal (dolichocephalous - Russian greyhound, collies),

3. combined (mezzo cephalous - German shepherd, Irish setter).

These changes condition the rotation of the face in relation to the skull base. With a vertical type, a face rotation is backward, with a horizontal type it is 
Acta Veterinaria (Beograd), Vol. 59. No. 2-3, 255-265, 2009.

expressively forward, but with a combined type it is somewhat less backward and more forward.

With the backward rotation, the frontal height of the face is increasing (brachycephalous type), with the forward rotation, the rear height of the face is increasing. During the combined type of growth, where the backward rotation is minimally expressed, the rear height of the face (limited with the points S-Go) is $45 \%$ of the frontal and medium face heights (lines N-Me; NIv). If the backward face rotation is expressed, the above percentage decreases, but at the same time the frontal facial rotation is increasing.

With reference to the above said, the term polygon has been introduced by Bjork (1947). This being the space marked at the rear end of the face with the line $\mathrm{N}-\mathrm{S}$. The lines S-Ar, and Ar-Go are the sides of the polygon. Go-Iv, Iv-Me and N-Me close the space marked as a polygon. In order to define the type of face growth and the changes in the relationship between the face and skull base, it is necessary to measure the size of the angles constructed by the above mentioned lines and to calculate their total. Analysis of the so obtained values of the polygon angles gives an insight into the specific type of viscerocranial growth. Our results have shown: firstly, a great stability of the numerical values of the polygon angles; secondly, the total sum of these angles shows a very low coefficient of variation $(\mathrm{CV}=2.6 \%)$; thirdly, a total measurement of the head polygon angles $(\Sigma=526.9$ degrees) is used to analyze the estimated face growth. If this total is less than the standard values obtained in our study, the face is growing by the rotation directed forward and upward, and vice versa. The results obtained indicate small individual differences in X-ray-craniometry of the head of the German Shepherd dog.

Thus, it can be concluded that the significance of radiocraniometric and radiocephalometric examinations is primarily shown in obtaining the exact data which may prove that the craniofacial system is within either harmonious or disharmonious relations, or it bears some deviations which will exclude that individual from what is supposed to be the ideal type. These measurements have defined the extent to which individual variations in the appearance of the head could be tolerated during selection of the German Shepherd. In the view of veterinary dentistry, they made it possible find out the prognosis and needed corrections of anomalies in the stomatognatic system.

Address for correspondence:

Prof. dr Nikola Krstić

Faculty of veterinary medicine

Department of radiology

11000 Belgrade

Bul. oslobođenja 18

E- mail: dr.nikola.kr@gmail.com

\section{REFERENCES}

1. Angle EH, 1913, Oklusions Anomalien der Zahne, H Meusner Verlog, Berlin.

2. Bimler HP, 1967, A roentgenoscopic method of analysing the facial correlations, Trans EOS, 241-53.

3. Bjork A, 1947, The face in profile, Beringska Boktryckeriet, Lund. 
4. Bodmer WF, Cavalli-Sforza LL, 1976, Genetics, Evolution and Man, WH Freeman and Co., San Francisco.

5. Broadbent HB, 1931, A new X-ray technique and its application to orthodontia, Angle orth, 1, 45-6.

6. Clutton - Brock J, Corbet GB, Hills M, 1976, A review of the family Canidae with a classification by numerical methods, Bull Brit Museum Zool, 29, 3, 1-99.

7. Dixon GH, Stewart RE, 1976, Genetic Aspects of anomalous tooth development, VRE Stewart and GH Prescott, Oral Facial Genetics, CV Mosby Co., St. Louis.

8. Downs WB, 1948, Variation in facial relationships: their significance in treatment and prognosis, $A J$ $0,34,812-40$.

9. Gans BJ, Sarnat BG, 1989, Sutural Facial Growth of the Macaca rhesus, Am J Orthod Dentofacial Orthop, 96, 5, 405-15.

10. Goldstein GS, 1988, Orthodontics - starting Point, J Vet Dent, 5, 1, 9.

11. Goodman RM, Corlin RJ, 1977, Atlas of the Face in Genetic Disorders (2nd ed.), C.V. Mosby Co., St. Louis.

12. Hollier LH, Rowe NM, Mackool RJ, Williams JK, Kim JH, Longaker MT et al, 2000, Controlled multiplanar distraction of the mandible. Part III: Laboratory studies of saggital (anteroposterior) and horizontal (mediolateral) movements, J Craniofac Surg, 11, 2, 83-95.

13. Hoffer OL, 1954, Interpretation du teleradiogramme a l'aide du radiogramme craniofacial en orthopedie maxillofaciale, Orth Franc, 25, 319.

14. Hofrath $H, 1931$, Die Bedeutung des Rontgenfern und Abstandsaufnahme fiir de Diagnostik der Kieferanomalien, Fortschr der Kieferorth, Bd. 2, 232-58.

15. Kavanagh TH, 1988, Case Report: Locating a Migrating Canine Tooth, with X-ray, J Vet Dent, 5, 1, 13-4.

16. Korkhaus C, 1936, Die Auswertung des Fernrontgenbildes in der Kieferorthopadie, Deutsche Zahn Mund Kieferheilk, Bd. 3, 715-29.

17. Korkhaus C, 1936, L'utilisation des teleradiographies dans le diagnostic des malformations dentofaciales, Orthod frang, 131-52.

18. Kraut JM, 1990, Veterinary Orthodontics, Am J Orthod Dentofcial Orthop, 98, 1, 19-21.

19. Krstić N, Milosavljević Z, Tepavčević Z, 2002, Roendgencraniometric and roendgencephalometric determination of linear parameters on dogs of German shepherd breed, Acta Vet Beograd, 52, 2-3, 181-96.

20. Kyle MA, 1988, Canine Periodontal Desease, J Vet Dent, 5, 1, 10-1.

21. Liou J, Polley W, Figueroa A, 1998, Distraction osteogenesis: the effects of orthodontic tooth movement on distracted mandibular bone, J Craniofac Surg, 9, 6, 564-71.

22. Lundstrom A, 1948, Tooth Size and Occlusion in Twins, S Karger, Basel.

23. McKeonin M, 1975, Craniofacial variability and its relationship to disharmony of the jaws and teeth, $J$ Anat, 119, 3, 579-88.

24. Nadjmi V, Van Erum R, Schoenaers J, Schepers E, 2003, Maxillary distraction using a trans-sinusal distractor technical note, Int J Oral Maxillofac Surg, 32, 5, 553-9.

25. Ross DL, 1986, Orthodontics for the Dog - Treatment Methods, Vet Clin North Am Small Anim Pract, $16,5,939-54$.

26. Sassouni V, 1955, A roentgenographic cephalometric analysis of cephalo-facio-dental relationships, AJO, 43, 735-64.

27. Scott JH, 1964, Introduction to Dental Anatomy, Livingstone, Edinburgh-London.

28. Scott JH, 1967, Dento-facial Development and Growth, Pergamon Press, Oxford-LondonEdinburgh.

29. Steiner CC, 1953, Cephalometrics for you and me, AJO, 39, 729-55.

30. Wang Y, Shi B, Li Y, Zheng Q, Deng DZ, 2006, Comparative study of maxillary growth and occlusal outcome after autogenous rib grafting in complete cleft palate defects, J Craniofac Surg, 17,1, 68-79.

31. Whyllie W, 1947, The assesment of antero-posterior dysplasia, Angle orth, 17, 97-109. 
Acta Veterinaria (Beograd), Vol. 59. No. 2-3, 255-265, 2009.

Krstić $\mathrm{N}$ et al.: X-ray craniometric and X-ray cephalometric

determination of angular parameters in German Shepherd dogs

\title{
RENDGENKRANIOMETRIJSKO I RENDGENKEFALOMETRIJSKO ODREĐIVANJE ANGULARNIH PARAMETARA KOD PASA RASE NEMAČKI OVČAR
}

\author{
KRSTIĆ N, PEŠUT OLIVERA, MARKOVIĆ D, TEPČEVIĆ ZVEZDANA, HADŽI MILIĆ M i \\ MILOSAVLJEVIĆ Ž
}

\section{SADRŽAJ}

Telerendgenske analize viscerokranijalnih parametara su izbegavane usled toga što referentne tačke za linearna i angularna merenja nisu bile definisane. U našem radu, klasifikovani su elementi koji se odnose na ravnotežu skeletnih struktura i zuba u odnosu na ostale kostne anatomske entitete glave. Prostorni odnosi na kostnom sistemu glave pasa rase nemački ovčar, utvrđeni su konstrukcijom i numeričkim određivanjem najznačajnijih uglovnih parametara: gonijalni ugao Go, uglovi Iv, SNA, SNB, ANB, NSBa. Sagitalni položaji ili nagibi gornjih i donjih sekutića određeni su preko uglova $\mathrm{C}$ i D, a odnos između ova dva parametra konstrukcijom interincizalnog ugla E. Položaj gornjih i donjih očnjaka u odnosu na osnovnu ravan maksile i mandibule determinisan je egzaktnim numeričkim vrednostima uglova F i G. Definisanje tipa rasta lica i promene odnosa lica i baze lobanje omogućeno je formiranjem sledećih uglova poligona, kao i egzaktnim određivanjem njihovih pojedinačnih i zbirnih vrednosti: <SarGo, <NSAr, <ArGolv, <GolvMe. 